\title{
A kiküldetés adminisztratív követelményeinek gyakorlati érvényesülése a Čepelnik-ügy prizmáján keresztül
}

\section{The Practical Functionality of Administrative Requirements of Posting through the Aspects of the Čepelnik Case}

A C-33/17. sz. Čepelnik-ügyben az Európai Unió Bíróságának arról kellett határoznia, hogy ellentétes-e az uniós joggal az olyan tagállami szabályozás, amely lehetővé teszi, hogy a szolgáltatás igénybe vevőjét arra kötelezzék, hogy függessze fel a kifizetéseket, és a valamely más tagállamban letelepedett szolgáltatásnyújtóra az elsô tagállam munkajogi szabályainak megsértése esetén esetlegesen kiszabható bírság megfizetésének biztositása céljából biztositékot nyújtson. Bár a jelen ügyre nem alkalmazható közvetlenül a kiküldött munkavállalók végrehajtási irányelve, hiszen az alapeljárás tényállása ezen irányelv nemzeti jogba történö átültetését megeloozően valósult meg, a Bíróság ítélete minden bizonnyal útmutatásul szolgál a munkavállalók kiküldetésének szabályozása keretében a tagállamok által bevezethetô adminisztrativ követelmények és ellenörzési intézkedések felülvizsgálata során.

Kulcsszavak: kiküldött munkavállaló, EU belső piac, szolgáltatásnyújtás szabadsága, Čepelnik, adminisztratív követelmények, ellenőrzési intézkedések

In case C-33/17 Čepelnik, the Court of Justice of the European Union (CJEU) had to determine whether the legislation of a Member State under which a recipient of services can be ordered to suspend payments and to pay a security to guarantee payment of a possible fine which might be imposed on the provider of services, established in another Member State, for an infringement of the labour law of the first Member State is contrary to the EU law. Although in the present case the CJEU could not rule on the basis of the Posting of Workers Enforcement Directive, as this

Fekete Sára, ELTE ÁJK Nemzetközi Magánjogi és Európai Gazdasági Jogi Tanszék, PhD-hallgató. E-mail: dr.fekete.sara@gmail.com 
was implemented into the national law after the facts at issue in the main proceedings took place, the CJEU's ruling provides useful insights into the future review of the admissibility of administrative requirements and control measures introduced at national level to monitor compliance with the posted worker regulations.

Keywords: posted worker, EU Single Market, free movement of services, Čepelnik case, administrative requirements, control measures

\section{Bevezetés}

A Čepelnik-ügy ${ }^{1}$ az Európai Unió Bíróságának (a továbbiakban: Bíróság) a munkavállalók védelme, a csalás - és legfőképpen társadalombiztosítási csalás - elleni küzdelem és a visszaélések megelőzése területén hozott egyik legújabb ítélete.

Ennek az ügynek a munkavállalók szabad mozgása és a szolgáltatásnyújtás szabadsága terén kiemelkedő jelentősége van, hiszen iránymutatást nyújt a Bíróság által a kiküldetési irányelvben, ${ }^{2}$ valamint a végrehajtási irányelvben ${ }^{3}$ foglalt célkitǔzések eléréséhez szükséges nemzeti intézkedések arányosságának értékelése során.

A Čepelnik-ügy a Bíróság által korábbi ügyekben ${ }^{4}$ megállapított értelmezést követi a munkavállalók jogainak és egyidejűleg a belső piacon történő szolgáltatásnyújtás szabadságának védelmét célzó nemzeti intézkedések megengedhetőségét illetően. A tagállamok nemzeti jogába 2016 júniusától kezdődően átültetett, a munkavállalók kiküldetésével kapcsolatos végrehajtási irányelv részben e korábbi joggyakorlat összefoglalását tartalmazza.

A Bíróság Čepelnik-ügyben hozott ítélete nem értelmezi magát a végrehajtási irányelvet, hiszen az annak időbeli hatálya miatt nem alkalmazható az alapügy tárgyát képező tényállásra. Mindazonáltal, a Bíróság ítélete, valamint annak átültetése az osztrák bíróságok előtt folyamatban lévő eljárásban kétségkívül precedensértékkel rendelkezik a tagállamok által a nemzeti jogba bevezetett adminisztratív követelmények és ellenőrzési intézkedések felülvizsgálatához, annak érdekében, hogy ezek ne akadályozhassák az uniós szintủ szolgáltatásnyújtást.

C-33/17. sz. Čepelnik-ügy [ECLI:EU:C:2018:1022].

Az Európai Parlament és a Tanács 96/71/EK irányelve (1996. december 16.) a munkavállalók szolgáltatások nyújtása keretében történő kiküldetéséről, HL L 18., 1997.1.21., 1-6. (magyar különkiadás 5. fejezet, 2 kötet, 431-436.)

3 Az Európai Parlament és a Tanács 2014/67/EU irányelve (2014. május 15.) a munkavállalók szolgáltatások nyújtása keretében történő kiküldetéséről szóló 96/71/EK irányelv érvényesítéséről és a belső piaci információs rendszer keretében történő igazgatási együttmúködésről szóló 1024/2012/EU rendelet (az IMI-rendelet) módosításáról, HL L 159, 8.5.2014, 11-31.

4 Különösen a Belgiumban bevezetett LIMOSA-rendszer képezte tárgyát a Bíróság felülvizsgálatának, mivel a külföldi vállalkozásoktól bekért információ nagy száma alkalmasnak minősült a szolgáltatásnyújtás szabadságának korlátozására (Alsos-Odegård, 2018:5). Lásd továbbá: a C-369/96. sz. Arblade és a C-376/96. sz. Leloup és Sofrage egyesített ügyeket [ECLI:EU:C:1999:575]. 


\section{A Čepelnik elözménye - a kiküldött munkavállalók végrehajtási irányelve}

A munkavállalók kiküldetése egy összetett jogintézmény, amely a munkavállalók szabad mozgása, valamint a szolgáltatásnyújtás szabadságának metszéspontjában található. Jogi szempontból a munkavállalók kiküldetése az Európai Unió Bíróságának ítélkezési gyakorlata ${ }^{5}$ szerint a szolgáltatásnyújtás szabadságához kapcsolódik abban az esetben is, ha a szolgáltatást „munkavállalók” nyújtják. (Gellérné, 2011:18) A kiküldött munkavállalók beazonosítása, megkülönböztetése a személyek szabad mozgását élvező uniós polgároktól, valamint az őket megillető jogok meghatározása és érvényesítése a mai napig vita tárgyát képezi. (Fekete, 2018a:28)

Akárcsak tagállami szinten, a munkavállalók uniós szintú védelme nem biztosítható pusztán az őket illető jogok meghatározása által: megfelelő végrehajtási mechanizmusokat kell létrehozni annak érdekében, hogy a munkavállalók élvezhessék is e jogaikat. (Kullmann, 2013:283) A munkavállalók kiküldetése egyedi kihívásokat támaszt a tagállamok munkaügyi felügyeletei, valamint végrehajtási szervei számára. (Čaněk et al., 2018:8) Míg a multinacionális vállalkozások szabadon nyújtanak határon átnyúló szolgáltatásokat, a nemzeti munkaügyi felügyeletek (és általában a nemzeti hatóságok) - a multinacionális vállalatok ellenőrzése, valamint a kiküldött munkavállalók jogainak végrehajtása során - szervezeti és jogi/hatásköri megkötések miatt kötelesek szem előtt tartani a joghatóságukból fakadó korlátozásokat, valamint tiszteletben tartani a munkavállalókat megillető szabad mozgás elvét. Az EU-tagállamok nemzeti végrehajtási rendszerei strukturálisan különböznek egymástól, ${ }^{6}$ és ezáltal egymástól eltérő kihívásokkal, valamint szervezetikapacitás-problémákkal néznek szembe a munkajogok érvényesítése során. ${ }^{7}$

Az Európai Bizottság (a továbbiakban: Bizottság) 2012-ben terjesztette elő a kiküldött munkavállalókat érintő végrehajtási irányelv tervezetét, ${ }^{8}$ Andor László foglalkoztatásért, szociális ügyekért és társadalmi összetartozásért felelős biztos felügyelete alatt, a Bizottság által 2012 áprilisában közzétett foglalkoztatási csomag keretében. ${ }^{9}$ Az irányelvtervezet számos uniós szintű tárgyalás következményeként született meg,

5 Lásd különösen a C-113/89. sz. Rush Portuguesa Ld $^{\mathrm{a}}$ v Office national d'immigration ügy [ECLI:EU: C:1990:142].

$6 \quad$ A nemzeti hatóságok eljárási különbségeinek részletes leírásáért lásd Hartlapp elemzését a nemzeti végrehajtási rendszerek változásáról, valamint az azok közötti horizontális együttmúködéséről; Hartlapp az EU-15 tagállamok munkaügyi felügyeleteinek múködését vizsgálta 2000. és 2010. között. (Hartlapp, 2014)

7 A vizsgálatok, végrehajtás és együttmüködés terén fennálló különbségek tekintetében lásd: (van Hoek-Houwerzijl, 2011:4. fejezet)

8 Javaslat európai parlamenti és tanácsi irányelvre a munkavállalók szolgáltatások nyújtása keretében történő kiküldetéséről szóló 96/71/EK irányelv érvényesítéséről. [COM(2012) 131 final]

https://ec.europa.eu/social/main.jsp?langId=en\&catId=1039 (A letöltés dátuma: 2019. 07. 23.)

Európai Tükör 2019/3. 
a kiküldetési irányelv Bizottság által 2003-ban végrehajtott felülvizsgálatát, ${ }^{10}$ valamint az Európai Unió Bíróságának e tárgyban hozott (vitás) ítéleteit követően.

A kiküldetési irányelv felülvizsgálatáról szóló tárgyalások egybeestek a szolgáltatásnyújtás uniós szintű szabályozásával kapcsolatos egyeztetésekkel: 2002-ben a Bizottság jelentős korlátozásokat tárt fel a szabad szolgáltatási piac működését, s ezáltal az iparra és mezőgazdaságra összpontosító európai gazdaságnak a szolgáltatás-központú gazdasággá történő átállását illetően, és javaslatot tett a szolgáltatásnyújtás szabadságának az újraszabályozására a „gazdasági tevékenységek akadályainak elhárítása”, a „határokon átnyúló problémák megoldása”, valamint a „méretgazdaságosság előnyeinek kihasználása" érdekében. ${ }^{11}$ 2004-ben Bolkestein biztos nyilvánosságra hozta a szolgáltatási irányelv első tervezetét. A szolgáltatási irányelvet azonban a kezdetektől fogva bizalmatlansággal fogadták, a munkaügyi kapcsolatokat és a nemzeti munkajogokat érintő feltételezett negatív hatásai miatt. ${ }^{12}$

A Bíróság négy ítélete a Viking-Line, Laval, Rüffert és Bizottság kontra Luxemburg-azaz a „Laval négyes” - ügyekben ${ }^{13}$ felvetette a kérdést, hogy a tagállamok milyen mértékig avatkoznak be jogszerûen a kiküldetések során betartandó munkaügyi feltételek meghatározásába [azazhogy a kiküldetési irányelv 3. cikk (1) bekezdésében foglalt alapvető munka- és foglalkoztatási szabályok és feltételek egy kimerítő feltételrendszert alkotnak-e, amelyek a védelem minimumszintjét biztosítják], hogyan értelmezendők a „közrenddel kapcsolatos rendelkezések" a kiküldetések vonatkozásában, valamint hogy a szolgáltatásnyújtás szabadsága egy magasabb szintú elvet képvisel-e, mint a szakszervezeti jogok és a munkavállalók szociális jogai.

A kiküldött munkavállalók végrehajtási irányelve az egyik kulcsfontosságú eszköze az Európai Unión (korábban az Európai Gazdasági Térségen, valamint az Európai Közösségeken) belüli szabad szolgáltatásnyújtásnak a kiegyensúlyozásában, hiszen 20 évvel a belső piac létrehozását, és 15 évvel a munkavállalókat kiküldetés során megillető alapvető jogok szabályozását követően a szolgáltatások szabad áramlása még mindig nem nyerte el a teljes kihasználtságát, az európai piacok integrációja ellenére. Egyes szakértők úgy tartják, hogy a szolgáltatásnyújtás szabadságának teljes megvalósulása egy hibrid, egységes uniós munkajog létrehozását készíti elő. (Mussche et al., 2016:3)

A kiküldött munkavállalók végrehajtási irányelvét 2014 júniusában, több éven keresztül tartó tárgyalásokat követően fogadták el. Az irányelv célja a kiküldetési irányelvben foglalt rendelkezések betartatása azáltal, hogy követelményeket támaszt mind a tagállamokkal, mind a határokon átnyúló szolgáltatásokat nyújtó vállalkozásokkal szemben a kiküldött munkavállalók jogainak biztosítása, valamint a szociális dömping visszaszorítása érdekében. A végrehajtási irányelv átültetésével a tagállamoknak

10 Az Európai Bizottság jelentése a munkavállalók szolgáltatások nyújtása keretében történő kiküldetéséről szóló 96/71/EK irányelv átültetéséről, 2003. Elérhető: www.ec.europa.eu/social/postedworkers (A letöltés dátuma: 2019. 07. 23.)

11 Az Európai Bizottságnak a szolgáltatások belső piaci stratégiája első szakasza keretében a Tanácshoz és az Európai Parlamenthez jelentése a szolgáltatások belső piacának állapotáról, COM(2002) 441.

12 A szolgáltatási irányelv keletkezéséről lásd különösen: (Dǿlvik-Odegård, 2013; Schlachter-Fischinger, 2013)

13 AC-438/05. sz. Viking-ügy [ECLI:EU:C:2007:772], a C-341/05. sz. Laval-ügy [ECLI:EU:C:2007:809], aC-346/06. sz. Rüffert-ügy [ECLI:EU:C:2008:189], a C-319/06. sz. Bizottság kontra Luxemburg ügy [ECLI:EU:C:2008:350]. 
szigorú szabályokat kellett bevezetniük nemzeti szinten annak érdekében, hogy mihamarabb kiszűrjék a kiküldött munkavállalókkal kapcsolatos esetleges visszaéléseket és csalásokat, és megfelelő fórumot teremtsenek a kiküldött munkavállalók számára, hogy szükség esetén a kiküldő munkáltatóval szemben fellépjenek a jogaik érvényesítése érdekében. (Fekete, 2018b:74) E követelmények között találhatók olyan adminisztratív követelmények és ellenőrzési intézkedések, amelyek lehetővé teszik a kiküldetési irányelvben, valamint a végrehajtási irányelvben foglalt kötelezettségek teljesítésének a hatékony ellenőrzését.

A végrehajtási irányelv 9. cikke (1) bekezdése sorolja fel a tagállamok által bevezethető adminisztratív követelményeket. Így különösen a tagállamok mindenekelőtt az alábbi intézkedéseket írhatják elő:

a) a más tagállamban letelepedett szolgáltatókat terhelő, arra vonatkozó kötelezettség, hogy a felelös nemzeti illetékes hatóságoknak legkésőbb a szolgáltatásnyújtási tevékenység megkezdésekor egy egyszerü nyilatkozatot tegyenek a fogadó tagállam hivatalos nyelvén/nyelvein vagy a fogadó tagállam által elfogadott más nyelv(ek)en, amely tartalmazza az ahhoz szükséges releváns információkat, hogy a munkavégzés helyén ellenörizhetők legyenek a helyzetükkel kapcsolatos tények, többek között:

i. a szolgáltató kiléte;

ii. előzetes becslés az egyértelmüen azonosítható kiküldött munkavállalók számáról;

iii. az e) és f) pontban említett személyek;

iv. a kiküldetés tervezett idôtartama, kezdete és vége;

v. a munkavégzés helyének címe(i); valamint

vi. a kiküldetésre okot adó szolgáltatások jellege;

b) arra vonatkozó kötelezettség, hogy a munkaszerződést vagy egy, a 91/533/EGK tanácsi irányelv szerinti, azzal egyenértékü dokumentumot, beleértve adott esetben az említett irányelv 4. cikkében említett kiegészítö információkat is, a fizetési papírokat, a napi munkaidő kezdetét, végét és időtartamát feltüntető munkaidő-nyilvántartó lapokat és a bérkifizetést igazoló dokumentumokat vagy az ezekkel egyenértékú dokumentumok másolatát a kiküldetés ideje alatt megörizzék vagy rendelkezésre bocsássák és/vagy papíralapú vagy elektronikus másolatban megörizzék egy, a területükön - például a munkavégzés helyén vagy az épitési területen, vagy a közlekedési ágazatban dolgozó utazó munkavállalók esetében a tevékenység bázisán vagy a jármüben, amellyel a szolgáltatást nyújtják - hozzáférhetô és egyértelmüen meghatározott helyen;

c) a b) pontban emlitett dokumentumok átadásának kötelezettsége a kiküldetési idő lejártát követô ésszerü idôtartamon belül, a fogadó tagállam hatóságainak kérésére;

d) a b) pontban említett dokumentumoknak a fogadó tagállam hivatalos nyelvére/nyelveire vagy a fogadó tagállam által elfogadott más nyelv(ek)re történö lefordítására irányuló kötelezettség;

e) a szolgáltatásnyújtás helye szerinti fogadó tagállambeli illetékes hatóságokkal való kapcsolattartásért, valamint szükség szerint a dokumentumok és/vagy értesitések kiküldéséért és átvételéért felelős személy kijelölésének kötelezettsége;

f) képviselőként eljáró kapcsolattartó személy kinevezésének kötelezettsége, akin keresztül az érintett szociális partnerek a szolgáltatásnyújtás ideje alatt szükség esetén kapcsolatba léphetnek a szolgáltatóval a fogadó tagállamon belüli kollektív tárgyalások folytatására való felkérése céljából, a nemzeti jognakés/vagy gyakorlatnakmegfelelöen. 
Ez a személy lehet az e) pontban említettől eltérô személy, és nem szükséges a fogadó államban tartózkodnia, de ésszerú és indokolt kérés esetén rendelkezésre kell állnia.

Ezen intézkedéslista jelzésértékű és nem kizárólagos, amint azt maga az irányelv szövege is jelzi („a tagállamok mindenekelőtt az alábbi intézkedéseket írhatják elő”). Mindazonáltal, a tagállamok által bevezetett intézkedéseknek indokoltnak és arányosnak kell lenniük ${ }^{14}$ annak érdekében, hogy ne jelentsenek adminisztratív terhet, valamint ne korlátozzák a vállalkozásokban - különösen a kis- és középvállalkozásokban (kkv-k) - rejlő munkahelyteremtő potenciál kibontakozását. ${ }^{15}$ A munkavállalók kiküldetésével kapcsolatos eljárások és formai követelmények semmilyen esetben nem korlátozhatják a szolgáltatások szabad nyújtását az uniós belső piacon belül.

E körülmények között a szolgáltatásnyújtás szabadságának elve összeütközésbe kerülhet a nemzeti munkajogi követelményekkel. A Čepelnik-ügyben a Bíróság nagytanácsának arról kellett határoznia, hogy vajon az osztrák jogalkotó által bevezetett adminisztratív követelmények és ellenőrző intézkedések megfelelnek-e a szolgáltatási irányelv ${ }^{16}$ által bevezetett egyenlő bánásmód, szükségesség és arányosság követelményeinek, és vajon a bevezetett intézkedések indokolják-e a szolgáltatásnyújtás korlátozását közrendi, közbiztonsági, közegészségügyi vagy természetvédelmi szempontból.

\section{Tények, eljárás és az elözetes döntéshozatali kérdések}

A Bezirksgericht Bleiburg/Okrajno sodišče Pliberk (bleiburgi kerületi bíróság, Ausztria), által a Bíróság elé terjesztett előzetes döntéshozatali kérdésekben lényegében azt kérdezte a Bíróságtól, hogy tiltja-e az uniós jog, hogy valamely tagállam a megrendelőt, aki ugyanezen tagállamban valamilyen munkát rendel meg, arra kötelezze, hogy függessze fel a kifizetéseket, vagy a még fizetendő összegnek megfelelő biztosítékot nyújtson, ha a kifizetés ilyen felfüggesztése és az ilyen biztosíték kizárólag az ezen munkákat elvégző, valamely másik tagállamban letelepedett szolgáltatásnyújtóra utólagosan egy külön eljárásban kiszabható bírság megfizetésének biztosítására szolgál.

Annak érdekében, hogy meghatározza a nemzeti intézkedésnek az uniós joggal való összeegyeztethetőségét, mind Wahl főtanácsnok, ${ }^{17}$ mind a Bíróság megvizsgálták egyrészt az EUMSZ 56. cikkében a szolgáltatásnyújtás szabadságát illetően lefektetett rendelkezéseket, a szolgáltatási irányelvet, valamint a kiküldött munkavállalók végrehajtási irányelvét, másrészt azon nemzeti jogszabályokat, amelyek az érintett tagállam szerint a nemzeti munkajogi szabályozás részét képezik.

A Čepelnik-ügy felei egyrész a Čepelnik d. o.o., egy szlovéniai székhelyú társaság, másrészt Michael Vavti, aki részére a társaság építőipari szolgáltatásokat nyújtott 12200 euró értékben. A szolgáltatások nyújtására kiküldött munkavállalók segítségével

Végrehajtási irányelv 9. cikk (2) bekezdés.

Végrehajtási irányelv (4) preambulumbekezdése.

Az Európai Parlament és a Tanács 2006/123/EK irányelve (2006. december 12.) a belső piaci szolgáltatásokról, HL L 376, 2006. 12. 27., 36-68.

Wahl főtanácsnok 2018. május 8-i indítványa, C33/17 Čepelnik-ügyben [ECLI:EU:C:2018:311]. 
került sor egy Michael Vavti tulajdonában álló, Ausztriában található házban. Michael Vavti a Čepelniknek 7000 euró előleget fizetett.

2016-ban az osztrák pénzügyőrség ellenőrzést hajtott végre az építkezésen és megállapította, hogy a Čepelnik a munkaügyi szabályokat illetően két szabálysértést követett el: egyrészt, a helyszínen dolgozó két kiküldött munkavállalót nem jelentett be az osztrák hatóságokhoz, másrészt, a Čepelnik a kiküldetés ideje alatt nem őrzött német nyelvre lefordított bérkifizetést igazoló dokumentumokat négy kiküldött munkavállaló vonatkozásában.

Az Arbeitsvertragsrechts-Anpassungsgesetz (a munkaszerződésekre vonatkozó szabályozás kiigazításáról szóló osztrák törvény, BGBl. 459/1993, a továbbiakban: AVRAG) ugyanis előírta, hogy a munkáltatóknak legkésőbb a munka megkezdése előtt egy héttel be kell jelenteniük a kiküldött munkavállalók foglalkoztatását az illegális foglalkoztatást ellenőrző központi irodánál, ${ }^{18}$ és ellenőrzés esetére elérhetővé kell tennie a bérkifizetést igazoló dokumentumokat. ${ }^{19}$ Mindkét kötelezettség megszegése közigazgatási bírság kiszabását, valamint a kifizetések felfüggesztését és biztosíték fizetését vonja maga után abban az esetben, ha bizonyos körülmények miatt azt kell feltételezni, hogy a felelősségre vonás vagy a szankciók érvényesítése lehetetlen vagy jelentősen nehezebb lesz a munkáltatóval (vállalkozó) vagy a munkaerőt biztosító vállalkozással kapcsolatos okok miatt. ${ }^{20}$

Ennek megállapítását követően a pénzügyőrség Michael Vavtit a kifizetés felfüggesztésére kötelezte, és az illetékes közigazgatási hatóságtól (Bezirkshauptmannschaft Völkermarkt, völkermarkti elsőfokú közigazgatási hatóság; a továbbiakban: BHM Völkermarkt) Michael Vavtinak a Čepelnikre az ellenőrzés következtében induló eljárás keretében kiszabható bírságot fedező biztosíték nyújtására való kötelezését kérte. A pénzügyőrség azt kérte, hogy e biztosíték összegét a még fizetendő vállalkozói díj - azaz 5200 euró - összegben állapítsák meg. A BHM Völkermarkt helyt adott e kérelemnek és Michael Vavti befizette az ezen összegnek megfelelő biztosítékot. A Čepelnikkel szemben eljárást indítottak az állítólagos szabálysértések ügyében. 2016 októberében e szabálysértések miatt a Čepelnikre 1000, illetve 8000 eurós bírságot szabtak ki. A Čepelnik, miután befejezte a munkát, Michael Vavtinak 5000 euró összeget számlázott ki. Ez utóbbi megtagadta a követelt összeg kifizetését arra hivatkozva, hogy a BHM Völkermarktnak már 5200 eurós biztosítékot nyújtott. A Čepelnik ezt követően eljárást indított Michael Vavtival szemben a még ki nem fizetett vállalkozói díj megfizetése érdekében.

A kérdést előterjesztő bíróság azt kérdezte a Bíróságtól, hogy tiltja-e az uniós jog, hogy valamely tagállam a megrendelőt, aki ugyanezen tagállamban valamilyen munkát rendel meg, arra kötelezze, hogy függessze fel a kifizetéseket, vagy a még fizetendő összegnek megfelelő biztosítékot nyújtson, ha a kifizetés ilyen felfüggesztése és az ilyen biztosíték kizárólag az ezen munkákat elvégző, valamely másik tagállamban letelepedett szolgáltatásnyújtóra utólagosan egy külön eljárásban kiszabható bírság megfizetésének biztosítására szolgál.

AVRAG 7b. cikk (3) albekezdés.

AVRAG 7i. cikk (4) albekezdés.

AVRAG 7m. cikk.

Európai Tükör 2019/3. 
Különösen, a kérdést előterjesztő bíróság azt kérdezte, hogy tiltja-e az uniós jog a kifizetési tilalomnak és a kifizetetlen vállalkozói díjnak megfelelő összegú biztosíték megfizetésének az e tagállambeli megrendelővel szembeni elrendelését, ha a más uniós tagállamban székhellyel rendelkező szolgáltató, akivel szemben bírság kiszabására kerül sor, a biztosíték megfizetésének elrendelésére irányuló eljárásban nem élhet jogorvoslattal a biztosíték megfizetését elrendelő határozattal szemben, a megrendelő e határozattal szemben indított keresetének pedig nincs halasztó hatálya.

A főtanácsnok indítványa, valamint a Bíróság határozata által vizsgált főbb szempontok az előzetes döntéshozatali kérdések megválaszolására a következők voltak:

- amely uniós jogi rendelkezések vonatkoznak az alapügyre;

- a szóban forgó nemzeti intézkedések összeegyeztethetők-e az uniós joggal;

- a szóban forgó intézkedések (közvetlenül vagy közvetve) hátrányosan megkülönböztetők-e.

\section{Az alkalmazandó uniós jogi rendelkezések}

A főtanácsnok által megvizsgált első kérdés - amelyet később a Bíróság is értékelt - az alapügyre alkalmazandó uniós jogi rendelkezések megállapítására irányult. Ugyanis, míg a kérdést előterjesztő bíróság az EUMSZ 56. cikk és a kiküldött munkavállalók végrehajtási irányelvére alapozta kérdéseit, több érdekelt fél is jelezte észrevételeikben a Bíróság részére, hogy az előzetes döntéshozatali kérdéseket a szolgáltatási irányelvre (is) tekintettel kellene megválaszolni. ${ }^{21}$

Már az elején meg kell állapítani, amint azt a főtanácsnok is megjegyezte az indítványának 41. pontjában, és Bíróság is megerősítette az ítélete 27. pontjában, hogy a kiküldött munkavállalók végrehajtási irányelve, amely tárgyát illetően elvileg releváns lett volna, időbeli hatálya miatt mégsem alkalmazható az alapügyre, mivel annak tényállása 2016 márciusában következett be, azonban a végrehajtási irányelvet csupán 2016 júniusában ültették át az osztrák jogba, és 2017. január 1-jén lépett hatályba. Ugyanakkor a kiküldött munkavállalók végrehajtási irányelve alkalmazható lesz a szóban forgó intézkedéseket meghaladó bírság végrehajtására. ${ }^{22}$

Következésképpen felmerül a kérdés, hogy az alapügyre az EUMSZ 56. cikke alkalmazandó-e, amint arra az előzetes kérdést előterjesztő bíróság hivatkozott, vagy inkább a szolgáltatási irányelv rendelkezései. A szolgáltatási irányelv 1. cikk (6) bekezdése szerint ugyanakkor az irányelv nem érinti a munkajogot, azaz a foglalkoztatási feltételekre, a munkafeltételekre, köztük a munkaegészségügyi és munkabiztonsági feltételekre, valamint a munkaadók és a munkavállalók közötti kapcsolatokra vonatkozó,

Bíróság Čepelnik-ügyben hozott ítéletének 28. pontja.

Lásd: Wahl főtanácsnok indítványának 41. pontjához kapcsolódó 9. sz. lábjegyzet.

Európai Tükör 2019/3. 
a tagállamok által a közösségi jogot tiszteletben tartó nemzeti jognak megfelelően alkalmazott jogszabályi vagy szerződéses előírásokat. ${ }^{23}$

A Rina Services-ügyben ${ }^{24}$ először, és ezt követően a Bizottság kontra Magyarország ügytől ${ }^{25}$ kezdve a Bíróság következetesen a szolgáltatási irányelvben meghatározott „tesztet” alkalmazza azon keretrendszerként, amely alapján eldönti, hogy valamely nemzeti intézkedés összeegyeztethető-e a szolgáltatások szabadságának elvével, ha az említett intézkedések az említett jogszabály tárgyi hatálya alá tartoztak, és nem vizsgálja az intézkedéseket az EUMSZ 49 és/vagy EUMSZ 56. cikk alapján. ${ }^{26}$

A szolgáltatási irányelv főszabály szerint minden szolgáltatási tevékenységre és minden olyan nemzeti jogszabálytípusra alkalmazandó, amely korlátozhatja a szolgáltatások szabad mozgását, kivéve azokat a tevékenységeket és nemzeti jogszabálytípusokat, amelyek kifejezetten ki vannak zárva a hatálya alól. Az építési szolgáltatásokat - amely tevékenységről az alapeljárásban szó van - kifejezetten megemlíti a szolgáltatási irányelv (33) preambulumbekezdése az irányelv hatálya alá tartozó tevékenységek példájaként. ${ }^{27}$

Először is a Bíróságnak értékelnie kellett, hogy az AVRAG rendelkezései - és különösen annak $7 \mathrm{~m}$. cikke, amely bevezeti annak a lehetőségét, hogy az ügyfél vagy a munkáltató felfüggessze a fennmaradó összeg kifizetését, illetve hogy a szolgáltatás még ki nem fizetett értékét vagy annak egy részét biztosítékként megfizesse - azon munkajogi szabályok közé tartoznak-e, amelyek mentesülnek a szolgáltatási irányelv hatálya alól.

A főtanácsnok álláspontja szerint a „munkajog” fogalma kizárólag uniós fogalom lehet. Máskülönben az irányelv hatálya az egyes országokban elfogadott formális munkajogi fogalomtól függően tagállamok szerint változna. ${ }^{28}$ Ezen túlmenően, a főtanácsnok figyelembe vette, hogy a szolgáltatási irányelv 1. cikke (6) bekezdésében és a (14) preambulumbekezdésben szereplő fogalommeghatározás kellőképpen tágnak tűnik ahhoz, hogy a legtöbb, ha nem az összes olyan szempontot lefedje, amely alatt uniós vagy nemzetközi szinten jellemzően munkajogot értünk, beleértve a szóban forgó területre jellemző szankciókkal és eljárásokkal kapcsolatos szabályokat. Ahhoz, hogy valamely tagállam képes legyen alkalmazni munkajogát az olyan helyzetekre, amelyekre főszabály szerint a szolgáltatási irányelv alkalmazandó, szükségképpen rendelkeznie kell hatáskörrel azon szabályok alkalmazására, amelyek kifejezett célja, hogy az anyagi

23 E rendelkezést együtt kell olvasni a szolgáltatási irányelv (14) preambulumbekezdésével, amely szerint „[e]z az irányelv nem érinti a tagállamok által a közösségi jognak megfelelően alkalmazott foglalkoztatási feltételeket, így a maximális munkaidő és a minimális pihenőidő, a minimális fizetett éves szabadság, a minimális bérszint, a munkahelyi egészségvédelem, biztonság és higiénia szabályait, valamint a szociális partnerek közötti kapcsolatokat sem, beleértve a közösségi jogot tiszteletben tartó nemzeti joggal és gyakorlatokkal összhangban lévő, kollektív megállapodásokkal kapcsolatos tárgyalásokhoz és azok megkötéséhez, valamint a sztrájkhoz és a szervezett fellépéshez való jogot, és nem vonatkozik a munkaerő-kölcsönzők által nyújtott szolgáltatásokra sem. Az irányelv nem érinti a tagállamok szociális biztonsági jogszabályait".

24 C-593/13. sz. Rina Services és társai-ügy [ECLI:EU:C:2015:399], az ítélet 23. és azt követő pontja.

25 C-179/14. sz. Bizottság kontra Magyarország-ügy [ECLI:EU:C:2016:108], az ítélet 118. pontja.

26 A főtanácsnok Čepelnik-ügyben előterjesztett indítványának 43. pontja.

27 A főtanácsnok indítványának 45. pontja.

28 A főtanácsnok indítványának 55. pontja. 
munkajogi szabályokkal való hatékony, ellenőrizhető és kikényszeríthető megfelelést biztosítsa. ${ }^{29}$

A Čepelnik-ügyben ugyanakkor azon nemzeti szabályok, amelyek az érintett tagállam (Ausztria) szerint a munkajogi szabályozásának a részét képezik, nem tűnnek munkajogi jellegű szabályoknak, s ezáltal nem részesülhetnek a szolgáltatási irányelvben meghatározott „munkajogi” kivételek kedvezményében. A főtanácsnok álláspontját a következő megállapításokra alapozta: ${ }^{30}$

- az AVRAG 7m. cikkében foglalt intézkedést olyan helyzetre írják elő, ahol a munkajogi szabályok megsértése még nem bizonyosodott be, és ami még fontosabb, nem az állítólagos jogsértővel, hanem a vele szerződő féllel szemben rendelik el;

- a szerződő fél - akit a szóban forgó intézkedés közvetlenül és azonnal érint - a jogi helyzetét általában nem szabályozzák a munkajogi szabályok, mivel, legalábbis ebben a helyzetben, ő nem minősül sem munkáltatónak, sem munkavállalónak;

- a szóban forgó intézkedés révén behajtott pénzösszeg nem a munkavállalók védelmét vagy más szociális célkitűzést szolgálja.

A főtanácsnok szintén egyetértett az észrevételeket előterjesztő felekkel, hogy a szóban forgó intézkedés törvényi célkitűzése inkább az, hogy az államkincstár javára, a rendőrségi és közigazgatási hatáskört gyakorolva biztosítsa azon szankciók sikeres megfizettetését, amelyeket a közigazgatási szervek a jövőben a szolgáltatóval szemben kiszabnak. ${ }^{31}$

A De Clercq-ügyben ${ }^{32}$ a Bíróság már megállapította, hogy a kiküldött munkavállalók „munkaviszonyára vonatkozó szabályok” fogalma a kiküldetési irányelv vonatkozásában nem foglalja magában azon közigazgatási szabályokat, amelyek lehetővé teszik a hatóságok számára, hogy ellenőrizzék a kiküldött munkavállalók munkaviszonyára vonatkozó szabályoknak és feltételeknek való megfelelőséget.

A főtanácsnok indítványa ellenére a Bíróság ugyanakkor ítéletében úgy határozott, hogy az olyan nemzeti szabályozás, mint amilyenről az alapügyben szó van, a munkajog anyagi jogi szabályai, és az ezen anyagi jogi szabályok be nem tartása esetén kiszabott szankciók hatékonyságának garantálását célzó szabályok tiszteletben tartásának biztosítására irányuló, visszatartó erejü intézkedéseket állapít meg, hozzájárul az olyan közérdekű célok magas szintű védelmének biztosításához, mint a munkajognak való megfelelés szükségessége. ${ }^{33}$

Következésképpen megállapítható, hogy a főtanácsnoki indítvány és a Bíróság ítélete eltérnek a tekintetben, hogy a szóban forgó intézkedés a munkajog részét képezi-e, és ezáltal mentesül-e a szolgáltatási irányelvben foglalt rendelkezések alól.

Bár a főtanácsnok indítványában arra az álláspontra jutott, hogy a szóban forgó intézkedés nem tekinthető a tagállam munkajogi szabályozása alá esőnek a szolgáltatási irányelv szempontjából, így nem mentesülhet a szolgáltatási irányelv 16. és 19. cikkében foglalt követelmények alól, a Bíróság ítéletében megállapította, hogy a szolgáltatási irányelv nem alkalmazható az alapügyben tárgyát képező nemzeti szabályozásra.

A fő́tanácsnok indítványának 57-58. pontja.

A főtanácsnok indítványának 60 . pontja.

A fôtanácsnok indítványának 61 . pontja.

C-315/13. sz. De Clercq és társai-ügy [EU:C:2014:2408], az ítélet 42-48. pontja.

$\mathrm{Az}$ ítélet 34. pontja.

Európai Tükör 2019/3. 
A főtanácsnoki indítvány ellenére a Bíróság úgy határozott, hogy a szolgáltatási irányelv 1. cikke (6) bekezdése értelmében vett „munkajog” fogalma kiterjed az AVRAG $7 \mathrm{~m}$. cikkében foglalt intézkedésre ${ }^{34}$ mivel a Bíróság szerint - amint az a szolgáltatási irányelv (7) preambulumbekezdéséből kitűnik - az uniós jogalkotó ezen irányelv elfogadásával megpróbálta biztosítani az egyrészt a szolgáltatásnyújtók letelepedési szabadsága, valamint a szolgáltatások szabad mozgása akadályai megszüntetésének célkitűzése, másrészt a közérdekű célok - többek között a munkajognak való megfelelés - magas szintû védelmének biztosítására vonatkozó követelmény közötti egyensúly tiszteletben tartását. ${ }^{35}$

\section{Az uniós joggal való összeegyeztethetöség}

A Čepelnik-ügyben Wahl főtanácsnok elsősorban a szolgáltatási irányelv elemzésére, különösen annak IV. fejezetébe („A szolgáltatások szabad mozgása”) foglalt 16. és 19. cikkének értelmezésére alapozta indítványát: a 16. cikk meghatározza ezzel kapcsolatban a fő elveket, és különösen azokra a korlátozásokra helyezi a hangsúlyt, amelyek a szolgáltatókat érinthetik, míg a 19. cikk azokra a korlátozásokra vonatkozik, amelyek a szolgáltatások igénybe vevőit érinthetik. ${ }^{36}$

Végső soron a főtanácsnok amellett foglalt állást, hogy a szóban forgó intézkedés nem egyeztethető össze a szolgáltatási irányelv 16. és 19. cikkében foglalt korlátozásokkal, és nem igazolható az ugyanezen irányelv 17. és 18. cikkében szereplő eltérésekkel. ${ }^{37}$

A Bíróság ugyanakkor megállapította, hogy a szolgáltatási irányelv nem alkalmazandó az olyan intézkedésekre, mint amilyeneket az alapeljárás tárgyát képező nemzeti szabályozás előír, azzal együtt, hogy magának az ezen irányelv 1. cikke (6) bekezdése szövegének értelmében e megállapítás nem mentesít annak ellenőrzése alól, hogy az ilyen szabályozás megfelel-e az uniós jognak, különösen az EUMSZ 56. cikknek, amire a kérdést előterjesztő bíróság által feltett kérdések vonatkoznak. ${ }^{38}$

A szolgáltatási irányelv olyan általános jogi keretet hoz létre, amely előnyös a szolgáltatások széles köre számára, miközben figyelembe veszi a tevékenységek és szakmák valamennyi típusának sajátosságait és szabályozási rendszerét. Az irányelv célja, hogy támogassa egy olyan kiegyensúlyozott intézkedéscsomag meghozatalát, amely a célzott harmonizációt, az igazgatási együttmúködést, a szolgáltatásnyújtás szabadságáról való rendelkezést és - egyes kérdések tekintetében - magatartási kódex kidolgozásának ösztönzését foglalja magában. Ez az irányelv figyelembe vesz egyéb közérdekű célokat is, így a környezet védelmét, a közbiztonságot, a közegészséget és a munkajog rendelkezéseinek való megfelelést. ${ }^{39}$

Míg a szolgáltatási irányelv pozitív integráció, azaz az uniós jognak a nemzeti jogalkotásra gyakorolt harmonizációja útján kívánja elérni a szolgáltatások szabad áramlását,

Az ítélet 35. pontja.

Az ítélet 33. pontja.

A főtanácsnok indítványának 64 . pontja.

A főtanácsnok indítványának 80-83. pontja.

Az ítélet 36. pontja.

A szolgáltatási irányelv (7) preambulumbekezdése.

Európai Tükör 2019/3. 
az EUMSZ 56. cikkét általában a negatív integráció eszközeként tartják számon. (Cuyvers, 2017:388) Az EUMSZ 56. cikke ugyanis kimondja, hogy az EUMSZ IV. címének („A személyek, a szolgáltatások és a tőke szabad mozgása”) 3. fejezete („Szolgáltatások”) rendelkezéseinek megfelelően tilos az unión belüli szolgáltatásnyújtás szabadságára vonatkozó minden korlátozás a tagállamok olyan állampolgárai tekintetében, akik nem abban a tagállamban letelepedettek, mint a szolgáltatást igénybe vevő személy.

Az EUMSZ 56. cikke (az EKSz. korábbi 49. cikke) már számos alkalommal képezte a Bíróság értelmezésének tárgyát. ${ }^{40}$ A Bíróság állandó joggyakorlata értelmében a szolgáltatásnyújtás szabadsága korlátozásának tekintendő minden olyan intézkedés, amely e szabadság gyakorlását tiltja, zavarja, vagy kevésbé vonzóvá teszi. ${ }^{41}$ Ezenkívül az állandó ítélkezési gyakorlat szerint az EUMSZ 56. cikk nemcsak magának a szolgáltatás nyújtójának, hanem az említett szolgáltatásokat igénybe vevőnek is biztosít jogokat. ${ }^{42}$

Az EUMSZ 56. cikke szerinti korlátozás fogalmát a Bíróság először a Säger-ügyben dolgozta ki, kifejtve, hogy: ${ }^{43}$

„A Szerződés 59. [később EKSz 49., jelenleg EUMSZ 56.] cikke nemcsak a szolgáltatást nyújtó személlyel szembeni, minden, állampolgárságon alapuló hátrányos megkülönböztetés eltörlését követeli meg, hanem bármely olyan korlátozás eltörlését is, még ha az egyenlöen alkalmazandó a hazai és más tagállamból származó szolgáltatókra, amely alkalmas meggátolni, vagy másként akadályozni egy szolgáltató tevékenységét, aki egy másik tagállamban telepedett le, és ahol ö jogszerüen nyújt hasonló szolgáltatást."

Nincs szükség tehát hátrányos megkülönböztetésre ahhoz, hogy a szolgáltatásnyújtás korlátozása megvalósuljon, mivel a korlátozás már önmagában megvalósul azáltal, hogy egyáltalán felmerül annak a lehetősége, hogy a nemzeti szabályozás megnehezíti a határon átnyúló szolgáltatás nyújtását vagy az abban való részesülést. (Cuyvers, 2017:385)

Az állandó ítélkezési gyakorlat ${ }^{44}$ értelmében az EUMSZ 56. cikke megkívánja minden, a szolgáltatásnyújtás szabadságát korlátozó intézkedés eltörlését, abban az esetben is, ha e korlátozások megkülönböztetés nélkül alkalmazandók a hazai és más tagállamból származó szolgáltatókra, és e korlátozások alkalmasak arra, hogy tiltsák, meggátolják, vagy másként akadályozzák egy szolgáltató tevékenységét, aki egy másik tagállamban telepedett le, és ahol ő jogszerúen nyújt hasonló szolgáltatást.

A szolgáltatásnyújtás szabadsága mind a szolgáltatást nyújtó, mind az abban részesülő személyt kedvezi; az EUMSZ 56. cikke szerinti korlátozás csak akkor igazolható, ha az arányos és a kitűzött céllal összhangban van. A szolgáltatások esetén is az EUMSZ 51. és 52. cikke alapján megengedett törvényes célokat kiegészíti a bírói joggyakorlat által

\footnotetext{
$40 \quad$ Lásd például az Európai Bizottság útmutatóját az Európai Unió Bíróságának a EUMSZ 56. cikkét érintő joggyakorlatáról.

41 Az ítélet 37. pontja, valamint a C339/15. sz. Vanderborght-ügy [ECLI:EU:C:2017:335], az ítélet 61. pontja, valamint az ott hivatkozott ítélkezési gyakorlat.

42 Az ítélet 38. pontja, valamint a C498/10. sz. X ügy [ECLIEU:C:2012:635], az ítélet 23. pontja; a C-315/13. sz. De Clercq és társai-ügy [ECLI:EU:C:2014:2408], az ítélet 52. pontja.

C-76/90. sz. Säger-ügy [ECLI:EU:C:1991:331], az ítélet 12. pontja.

44 Lásd többek között: C42/07. sz. Liga Portuguesa de Futebol Profissional és Bwin Internationalügy [ECLI:EU:C:2009:519], az ítélet 51. pontja, valamint az ott hivatkozott ítélkezési gyakorlat; C-465/05. sz. Bizottság kontra Olaszország ítélet [ECLI:EU:C:2007:781], az ítélet 17. pontja, valamint a C-518/06. sz. Bizottság kontra Olaszország-ügy [ECLI:EU:C:2009:270], az ítélet 62. pontja.
} 
létrehozott, a józan mérlegelés elvén alapuló kifogások nyílt listája. A józan mérlegelés elve alapján a Bíróság már jóváhagyott több, a korlátozást igazoló célkitűzést (Cuyvers, 2017:386), beleértve a fogyasztóvédelmet, a kulturális politikát, a szolgáltatás szabad áramlásával való visszaélés megelőzését, a szolgáltatások kedvezményezettjeit védő szakmai szabályokat, illetve a lehetséges szociális dömping elleni, a fogadó tagállam munkavállalói védelmének érdekében történő kollektív jogérvényesítést. ${ }^{45}$

A jelen ügyben mind Wahl főtanácsnok, mind a Bíróság megvizsgálták, hogy az AVRAG 7m. cikkében foglalt intézkedés hátrányosan megkülönböztetőnek minősülhet-e, és amennyiben igen, az arányos-e, illetve megindokolható-e valamely törvényes célkitűzéssel.

\section{A szükségesség, arányosság és hátrányosan megkülönböztető jelleg vizsgálata}

A Čepelnik-ügyben az osztrák kormány fenntartotta álláspontját, miszerint az AVRAG 7m. cikke nem valósít meg hátrányos megkülönböztetést, mivel az Ausztriában, illetve a más tagállamokban székhellyel rendelkező szolgáltatókra egyaránt alkalmazandó. ${ }^{46}$ A tárgyaláson elhangzott kérdésre, hogy az osztrák törvény értelmében hasonló intézkedés volt-e alkalmazandó a kizárólag belső jellegű helyzetekre vagy az olyan szabálysértésekre, amelyeket általában inkább belföldi szolgáltatók követnek el, az osztrák kormány először igenlően felelt. Elemzésében ugyanakkor a főtanácsnok megállapította, hogy azok a szabálysértések, amelyek az AVRAG 7m. cikke alapján kiválthatják a szóban forgó intézkedés elfogadását (az ugyanazon törvény 7b. §-ának (8) bekezdésében, a 7i. §-ában és a 7k. §-ának (4) bekezdésében szereplő szabálysértések), mind a munkavállalók kiküldetésével kapcsolatos helyzetekre vonatkoznak. Ezért úgy tûnik, hogy a szóban forgó intézkedést kifejezetten a külföldi szolgáltatókra szabták, ${ }^{47}$ különösképpen, hogy a kérdést előterjesztő bíróság szerint a jelenleg tárgyalt ügyben az intézkedés alkalmazási feltételét azon egyszerủ oknál fogva tekintették teljesültnek, hogy a szolgáltató egy szlovén vállalkozás. Amennyiben ez így van, az említett rendelkezés de facto hátrányosan megkülönböztető: a külföldi szolgáltatók és a helyi szolgáltatók pusztán a székhelyük alapján részesülnek eltérő bánásmódban. ${ }^{48}$

Ugyanis, amint azt az indítványának 36-38. pontjában előadja, a főtanácsnok szerint a szóban forgó intézkedés természeténél fogva alkalmas arra, hogy egyfelől eltántorítsa az osztrák ügyfeleket attól, hogy külföldi székhelyű szolgáltatók szolgáltatásait vegyék igénybe, másfelől pedig eltántorítja a más tagállamokban székhellyel rendelkező szolgáltatókat attól, hogy ideiglenes jelleggel Ausztriában nyújtsanak szolgáltatást.

Márpedig egy olyan intézkedés, mint amilyenről szó van, nyilvánvalóan számos módon hátrányosan érinti azokat az ügyfeleket, akik külföldi szolgáltató szolgáltatásait

\footnotetext{
45 Lásd többek között: C-376/96. sz. Arblade-ügy [ECLI:EU:C:1999:575], az ítélet 35. pontja; C-341/05. sz. Laval-ügy [ECLI:EU:C:2007:809].

46 A fôtanácsnok indítványának 31. pontja.

47 A főtanácsnok indítványának 31. pontja.

48 A főtanácsnok indítványának 34. pontja.
} 
kívánják igénybe venni. A főtanácsnok indítványának 37. pontja sorolja fel a lehetséges hátrányos következményeket:

- ha a szóban forgó intézkedést elfogadták, az ügyfél számára még kinnlevő vállalkozói díjat haladéktalanul meg kell fizetnie a közigazgatási szerv részére, ahelyett, hogy megvárhatná, amíg a szolgáltató a szolgáltatást befejezi;

- az ügyfél elveszíti azt a lehetőséget, hogy a kifizetetlen díj egy részét visszatartsa a hibás vagy késedelmes teljesítés, vagy a munkálatok során okozott kár megtérítéseként;

- az ügyfél továbbá kiteszi magát annak a kockázatnak, hogy ha a szolgáltató az intézkedés alkalmazásáról tudomást szerez, a munkálatok leállnak vagy késedelmet szenvednek.

Másrészt, a szóban forgó intézkedés kevésbé vonzóvá teszi a külföldi székhelyű vállalkozások számára az Ausztriában történő ideiglenes szolgáltatásnyújtást: ${ }^{49}$

- elegendő az osztrák hatóságok „megalapozott gyanúja”, miszerint a szolgáltató az AVRAG bizonyos rendelkezései szerinti szabálysértést követett el, hogy elveszítse azt a jogot, hogy az ügyfelétől követelje a nyújtott szolgáltatás után járó, még kifizetetlen vállalkozói díjat;

- az a legkevesebb, hogy a szóban forgó intézkedés révén nagyobb a kockázata, hogy a szolgáltatók részére megkésve fizetik ki azt az összeget, amely többnyire a megállapodás szerinti teljes ár jelentős részét teszi ki;

- a szóban forgó intézkedés emellett bizonyos kedvezőtlen pénzügyi következményekkel járhat, még akkor is, ha szabálysértésre nem került sor, mivel a biztosíték a bírság kiszabására irányuló eljárás időtartama alatt (ami több évig is eltarthat) mindvégig az osztrák közigazgatási szerv számláján marad, ahol nem kamatozik.

Mind a főtanácsnok, mind a Bíróság egyetértenek abban, hogy egy olyan intézkedés, mint amilyenről itt szó van, a Szerződés szolgáltatásnyújtás szabadságáról szóló szabályainak hatálya alá tartozik. ${ }^{50} \mathrm{~A}$ Čepelnik-ügyben úgy tűnik, hogy a súlyos bírságok és a szóban forgó biztosítékok együttesen jelentősen akadályozzák a Szerződésekben biztosított szolgáltatásnyújtás szabadságát. Egyebek mellett az említett intézkedések együttesen jelentős mértékben módosítják a 96/71 irányelv által védett különböző (és időnként egymással versengő) érdekek között fennálló finom egyensúlyt: ezen érdekek a határokon átnyúló szolgáltatásnyújtásnak a tisztességes verseny biztosítása, valamint a munkavállalók jogainak a fogadó és székhely szerinti tagállamban való szavatolása melletti előmozdításához füződnek. ${ }^{51}$

Következésképpen az olyan intézkedéseket, mint amilyeneket az alapeljárás tárgyát képező nemzeti szabályozás előír, a szolgáltatásnyújtás szabadságát korlátozóknak kell tekinteni. ${ }^{52}$ A Čepelnik-ügyben a Bíróság megállapította, hogy az olyan tagállami

A fôtanácsnok indítványának 38. pontja.

A főtanácsnok indítványának 39. pontja.

A főtanácsnok indítványának 109. pontja.

Az ítélet 41. pontja. 
szabályozás, amely lehetővé teszi, hogy a szolgáltatás igénybe vevőjét arra kötelezzék, hogy függessze fel a kifizetéseket, és a valamely más tagállamban letelepedett szolgáltatásnyújtóra az első tagállam munkajogi szabályainak megsértése esetén esetlegesen kiszabható bírság megfizetésének biztosítása céljából biztosítékot nyújtson, meghaladja a munkavállalók védelmére, valamint a - többek között szociális biztonsági - csalás elleni küzdelemre és a visszaélések megelőzésére irányuló célkitűzések megvalósításához szükséges mértéket. ${ }^{53}$

\section{A Čepelnik-ügy tanulságai}

Bár a kiküldött munkavállalók végrehajtási irányelve - a 9. cikkében foglalt indikatív felsorolás útján - jól szemlélteti, hogy a tagállamok milyen adminisztratív intézkedéseket és ellenőrző mechanizmusokat vezethetnek be a nemzeti szabályozásukba, a Čepelnikügy a Bíróság szemszögéből mutatja be, hogy milyen szempontok alapján dönthető el, hogy a szóban forgó nemzeti intézkedések összeegyeztethetők-e a az uniós joggal. A tagállamoknak fel kell készülniük arra, hogy a munkavállalók jogainak biztosítása, és a szociális dömping elkerülése érdekében bevezetett intézkedéseiket felülvizsgálják abban az esetben, ha azok, illetve a hozzájuk kapcsolódó szankciók nem állnak arányban az általuk védelmezni kívánt törvényes célkitűzésekkel.

Ugyan a Čepelnik-ügyben nem született még jogerős határozat a bleiburgi kerületi bíróság előtt, már most megmutatkozik a Bíróság ítéletének hatása az osztrák, illetve a tágabb értelemben vett európai nemzeti joggyakorlatra a kiküldött munkavállalókkal kapcsolatos adminisztratív követelmények vonatkozásában.

Ausztriában a Landesverwaltungsgericht Niederösterreich (Alsó-Ausztria tartományi közigazgatási bírósága) az előtte folyamatban lévő ügyben ${ }^{54}$ - a Bíróságnak a Čepelnikügyben hozott ítéletére hivatkozással - 2019. február 1-jén úgy határozott, hogy az eljárás tárgyát képező, kiküldött munkavállalókat bejelentő nyilatkozat késedelmes benyújtása, valamint a kiküldetésekre vonatkozó dokumentáció hiányosságai miatt a kifizetések felfüggesztését és a biztosíték megfizetését elrendelő határozatot vissza kell vonni.

Ezen osztrák ügy tényállása kísértetiesen hasonlít a Čepelnik-ügyben tárgyaltakra: az osztrák adóhatóság által 2018 szeptemberében végrehajtott ellenőrzés során a hatóságok tudomására jutott, hogy az Ausztriában szolgáltatást nyújtó, Szlovákiában bejegyzett társaság négy munkavállalója nem lett időben bejelentve a hatóságokhoz, továbbá e kiküldött munkavállalók vonatkozásában a szlovák társaság nem tartotta nyilván a szükséges társadalombiztosítási igazolásokat (A1/E 101 igazolásokat), sem az előírt bérfizetési bizonylatokat; ezáltal az osztrák adóhatóság szerint a szlovák társaság megsértette az AVRAG-ot felváltó Lohn- und Sozialdumping-Bekämpfungsgesetz (bér-és szociális dömping elleni küzdelemről szóló törvény; LSD-BG) rendelkezéseit.

Egy hasonló ügyben az AVRAG 7m. cikkét helyettesítő LSD-BG 34. cikkének értelmezése ugyancsak bírósági eljárás tárgyát képezte: az osztrák Alkotmánybíróságnak

A Bíróság 170/18. sz. sajtóközleménye, 2018. november 13.

Ügyszám: LVwG-S-2688/001-2018; ECLI: AT: LVWGNI: 2019: LVwG.S.2688.001.2018.

Európai Tükör 2019/3. 
határoznia kellett arról, hogy az abban foglalt intézkedések alkotmányellenesnek minősülnek-e. ${ }^{55} \mathrm{Az}$ Alkotmánybíróság elé utalt egyik ügyet tárgyaló Landesverwaltungsgericht Oberösterreich (Felső-Ausztria tartományi közigazgatási bírósága) szerint e rendelkezések ugyanis:

- sértik az egyenlő bánásmód elvét, amennyiben a hazai szerződő félnek biztosítékot kell fizetnie annak ellenére, hogy nem ő, hanem a külföldi szolgáltató áll a szabálysértés elkövetésének gyanúja alatt; bár a biztosíték nem minősül bírságnak, lényegében egy harmadik személyek tartozásaiért való (alkotmányellenes) felelősséget valósít meg;

- sértik a független harmadik személy tulajdonjogát, amennyiben végső soron a közigazgatási eljárás a helyszínen fellelhető használati tárgyak lefoglalásával is végződhet;

- sértik a külföldi szolgáltatóknak a tisztességes eljáráshoz való jogát, hiszen a külföldi vállalkozásoktól rendszerint megtagadják a fél jogállását a biztosítékadás elrendeléséről szóló eljárás során;

- általában véve alkalmasak a szolgáltatásnyújtás szabadsága uniós elvének a korlátozására annyiban, amennyiben az jelentősen megnehezíti a más tagállamban letelepedett vállalkozások számára az Ausztriában történő szolgáltatásnyújtást.

Az Osztrák Munkáskamara és az Osztrák Szociáldemokrata Párt a Čepelnik-ügyben született határozatra hivatkozva támogatják az Európai Munkaügyi Hatóság gyors létrehozását: a jelen körülmények között az uniós jog által biztosított határokon átnyúló végrehajtási rendszer nem múködik, ezért az Európai Munkaügyi Hatóság feladatának kell lennie a munkabérekkel való visszaélések és a szociális dömping megakadályozása. ${ }^{56}$

Magyarország közvetlenül érintett a kiküldött munkavállalók végrehajtási irányelvét értelmező bírósági joggyakorlat által. A jelenleg is folyamatban lévő C-16/18. sz. Michael Dobersberger (a Magistrat der Stadt Wien részvételével) ${ }^{57}$ ügyben a Bíróságnak arra a kérdésre kell választ adnia, hogy hogyan alkalmazandók az irányelv által előírt adminisztratív intézkedések és ellenőrző mechanizmusok - különösen a munkavállalók határokon átnyúló kiküldetésének a fogadó tagállam hatósága részére vonatkozó bejelentése és e munkavállalók díjazásának mértékével és társadalombiztosítási bejelentésével kapcsolatos dokumentumok rendelkezésre tartása - a Magyarország és Ausztria között közlekedő vonatokon fedélzeti kiszolgálással, valamint ételek és italok készítésével és értékesítésével megbízott utazó személyzetére vonatkozóan. Az osztrák AVRAG ugyanis e „kiküldött” munkavállalók vonatkozásában is előírja a bejelentési és dokumentációs kötelezettséget. Bár az ügyben eljáró főtanácsnok álláspontja szerint az „intenzíven utazó munkavállalókra” nem terjed ki a kiküldetési - és ennek következtében

$55 \quad$ Lásd a 2018. december 12-i G104 / 2018 és társai-ügyben hozott ítélet 5.1-5.5 pontját. Az osztrák Alkotmánybíróság végül elutasította az ügyet, mivel ítéletével közvetett módon befolyásolná az előterjesztő bíróságok határozatát.

56 https://diepresse.com/home/wirtschaft/recht/5529000/EUGericht-kippt-oesterreichische-Regelunggegen-Sozialdumping (A letöltés dátuma: 2019. 07. 23.)

57 A Bíróság előtt C-16/18. sz. Michael Dobersberger (a Magistrat der Stadt Wien részvételével) folyamatban lévő ügy [ECLI:EU:C:2019:638]. 
a végrehajtási - irányelv, ${ }^{58}$ a Bíróság feladata lesz annak meghatározása, hogy e tekintetben (is) aránytalannak minősíthetők-e az osztrák nemzeti jog által előírt adminisztratív intézkedések.

Svájc szintén élénk figyelemmel követte a Čepelnik-ügyben született uniós szintű határozathozatalt. (Daum, 2018) Bár nem tagja az Európai Uniónak, a svájci nemzeti szabályozás a kiküldetési irányelvhez hasonlóan rendelkezik a Svájcba kiküldött munkavállalókat megillető munkajogok és munkakörülmények biztosításáról, valamint az azok betartását elősegítő bejelentési kötelezettségről. A svájci szakszervezetek szövetsége a Čepelnik-ügyre hivatkozással függesztette fel tárgyalását a Svájci Szövetségi Tanáccsal, amely tovább szigorította volna az uniós munkavállalókra vonatkozó kiküldetési szabályokat a bérdömping és az elégtelen munkakörülmények elleni harc keretében. A Čepelnik-ügyben hozott ítélet ugyanis további bizonyítékként szolgál arra a korábban elkezdett uniós gyakorlatra: kétség esetén mind a Bíróság, mind az Európai Bizottság a szolgáltatásnyújtás szabadságát helyezi előnybe a munkavállalók védelmével szemben, és felülírják az „egyenlő munkáért egyenlő bért” elvét. Minthogy a Čepelnik-ügy nyomán a Bíróságnak és az Európai Bizottságnak lehetősége nyílik felülvizsgálni a kiküldetések keretében hozott adminisztratív intézkedéseket, az ezzel kapcsolatos joggyakorlat kötelezővé válik a Svájci Szövetségi Tanács, valamint a svájci szakszervezetek számára is, megnyitva a munkaerőpiacukat a versenyképesebb uniós fizetések előtt.

Tekintettel arra, hogy a kiküldött munkavállalók végrehajtási irányelvének felülvizsgálata a következő hetekben esedékes - a Bizottságnak ugyanis legkésőbb 2019. június 18-ig kell jelentést benyújtania az Európai Parlamentnek, a Tanácsnak és az Európai Gazdasági és Szociális Bizottságnak az ezen irányelv alkalmazásáról és végrehajtásáról, adott esetben szükséges módosításokat vagy kiigazításokat javasolva - várhatóan több eljárást kezdeményeznek a Bíróság előtt, ${ }^{59}$ egyes nemzeti szabályoknak az uniós joggal való összeegyeztethetőségének megállapítása céljából. Az Európai Munkaügyi Hatóság (European Labour Authority - ELA) felállítása és a kiküldött munkavállalók szabályozásának e központi szerv alá rendelése szintén a kiküldött munkavállalók végrehajtási irányelvének egységesebb alkalmazását vetíti előre, annak ellenére, hogy az ELA-nak a munkaügyi ellenőrzésekben betöltött szerepét illetően a tagállamok között nem teljes az összhang. (Gellérné, 2018:13)

Csak az idő a megmondhatója, hogy vajon ez az ügy alkalmas lesz-e arra, hogy a kiküldött munkavállalókat érintő - a nemzeti adminisztratív és ellenőrző intézkedések formájában megjelenő - gyakorlati követelmények és szankció rendszerének reformját elindítsa.

58 Szpunar főtanácsnok 2019. július 29-i indítványa, C16/18 Michael Dobersberger-ügyben [ECLI:EU: C:2019:638], 65. pont.

59 Lásd többek között a Bíróság előtt (időközben törölték) a C-64/18. sz. Maksimovic, a C-140/18. sz. Köfler és mások, a C-146/18. sz. Köfler és a C-148/18. sz. Köfler és mások folyamatban lévő ügyeket az osztrák adminisztratív követelményeknek és ellenőrzési intézményeknek az uniós joggal való összeegyeztethetőségéről. 


\section{Felhasznált irodalom}

Cuyvers, Armin (2017): Freedom of Establishment and the Freedom to Provide Services in the EU. In Ugirashebuja, Emmanuel - RuhangisA, John Eudes - Ottervangner, Tom - Cuyvers, Armin eds.: East African Community Law. Brill. 376-391. DOI: https://doi.org/10.1163/9789004322073_025

DǿLVIK, Jon Erik - ODEGÅRD, Anne Mette (2013): The Struggle over the Services Directive: The role of the European Parliament and the ETUC. In STEIN, Evju ed.: Cross-Border Services, Posting of Workers and Multilevel Governance. University of Oslo. 351-374.

Fekete, Sára (2018a): The Challenges of Defining Posted Workers. Magyar Munkajog/ Hungarian Labour Law, 1. sz. 22-45. http://hllj.hu/letolt/2018_1_a/A_02_ FeketeS_hllj_2018_1.pdf (A letöltés dátuma: 2019. 07. 23.)

FeKETE Sára (2018b): Gondolatok egy találkozó margójára - Emmanuel Macron és a kiküldött munkavállalók. THEMIS. 58-79. Elérhető: www.ajk.elte.hu/media/ cf/3e/9d2b86a14df0de8223223358be869b15481d14f8b9652ff725ea5143812d/ Themis_2018_jun.pdf (A letöltés dátuma: 2019. 07. 23.)

GelléRné LuKÁcS, Éva (2011): Free Movement of Persons - a Synthesis. In SomsSich, Réka - SzABADos, Tamás eds.: Central and Eastern European Countries after and before the accession. Budapest, ELTE ÁJK, 51-84.

GEllÉRnÉ LuKÁCS, Éva (2018): European Labour Authority: The guardian of posting within the EU? Magyar Munkajog/Hungarian Labour Law, 1. sz. 1-21. Elérhető: http://hllj.hu/letolt/2018_1_a/A_01_GellerneLukacs_hllj_2018_1.pdf (A letöltés dátuma: 2019. 07. 23.)

HARTLAPP, Miriam (2014): Enforcing Social Europe through Labour Inspectorates: Changes in Capacity and Cooperation across Europe. West European Politics, Vol. 37, No. 4. 805-824. DOI: https://doi.org/10.1080/01402382.2014.919772

Kullmann, Miriam (2013): The Principe of Effet Utile and Its Impacts on National Methods for Enforcing the Rights of Posted Workers. The International Journal of Comparative Labour Law and Industrial Relations, Vol. 29, No. 3. 283-304.

Schlachter, Monika - Fischinger, Philipp (2013): From Bolkestein to the Services Directive - and further. In STEIN, Evju ed.: Cross-Border Services, Posting of Workers and Multilevel Governance. University of Oslo. 375-412.

VAN HoEk, Aukje - HouwerzIJL, Mijke (2011): Complementary study on the legal aspects of the posting of workers in the framework of the provision of services in the European Union. University of Amsterdam, Final Report. Elérhető: http://ec.europa.eu/ social/BlobServlet?docId=7510\&langId=en (A letöltés dátuma: 2019. 07. 23.) 


\section{Internetes források}

Alsos, Kristin - ODEGÅRD, Anne Mette (2018): Improving data collection about posting and information provision on conditions. Fafo Report, SOLIDAR. Elérhető: www. solidar.org/system/downloads/attachments/000/000/854/original/Improving_ data_collection_about_posting_and_information_provision_on_conditions_ applicable_for_posted_workers_Report_updated_01.2019.pdf?1546865970 (A letöltés dátuma: 2019. 07. 23.)

ČAnĚK, Marek - KAlL, Kairit - Lillie, Nathan - WAllace, Amelia - HAidinger, Bettina (2018): Transnational Cooperation among Labour Regulation Enforcement Agencies in Europe: Challenges and Opportunities Related to the Posting of Workers. SOLIDAR. Elérhető: www.mobilelabour.eu/wp-content/uploads/2018/07/ TNC_Report_-_Challenges_and_Opportunities_Related_to_the_Posting_of_ Workers___Attachements.pdf. DOI: 10.13140/RG.2.2.25125.19687 (A letöltés dátuma: 2019. 07. 23.)

DAum, Mattias (2018): Die linke Angst vor Europa. Schweizer Gewerkschaften stellen sich gegen ein Rahmenabkommen mit der EU. Wovor fürchten sie sich? Elérhető: www.zeit. de/2018/34/schweizer-gewerkschaften-angst-rahmenabkommen-eu (A letöltés dátuma: 2019. 07. 23.)

EU-Gericht kippt österreichische Regelung gegen Sozialdumping (2018). Die Presse, 13. 11. 2018. Elérhető: https://diepresse.com/home/wirtschaft/recht/5529000/ EUGericht-kippt-oesterreichische-Regelung-gegen-Sozialdumping (A letöltés dátuma: 2019. 07. 23.)

Mussche, Kinke - CoRluy, Vincent - MARX, Ive (2016): The Rise of the Free Movements: How Posting Shapes a Hybrid Single European Labour Market. IZA Discussion Paper No. 10365. Elérhető: www.mobilelabour.eu/wp-content/uploads/2017/06/raportHow-posting-shapes-a-hybrid-single-European-Labour-Market-IZA-Institute-1. pdf (A letöltés dátuma: 2019. 07. 23.)

https://diepresse.com/home/wirtschaft/recht/5529000/EUGericht-kippt-

oesterreichische-Regelung-gegen-Sozialdumping (A letöltés dátuma: 2019. 07. 23.) https://ec.europa.eu/social/main.jsp?langId=en\&catId=1039 (A letöltés dátuma: 2019. 07. 23.)

www.ec.europa.eu/social/postedworkers (A letöltés dátuma: 2019. 07. 23.)

Európai Tükör 2019/3. 
